\title{
Dental Non-Metric Traits in a Pre-Conquest Sample "Calchaquí" From Argentina, South America
}

\author{
Rasgos Dentales No-métricos en una Muestra Pre-Conquista \\ "Calchaquí" de Argentina, América del Sur
}

"Gabriel A. Bollini; **Carlos David Rodríguez-Flórez \& *** Sonia E. Colantonio

\begin{abstract}
BOLlini G. A.; RODRÍGUEZ-FLÓREZ, C. D. \& COLANTONIO, S. E. Dental non-metric traits in a Pre-Conquest sample "Calchaquî" from Argentina, South America. Int. J. Morphol., 27(4):1063-1067, 2009.

SUMMARY: The present study was carried out with a Calchaquí human Pre-Conquest sample from Northwest of Argentina, with the aim of exploring the dental morphology patterns in this population. This study was carried out by means of a macroscopic analysis in permanent dentitions of 7 skulls. 40 dental non-mtetric traits were recorded using the ASU Dental Anthropology System. Percentages $>70 \%$ was found only in 4 traits. Calchaquí sample studied here is near to these values in shovel shape expression, but the results of this study suggest that a Sinodont pattern is no clear for this sample. To conclude, the present investigation provides additional, insightful elements for a description of biological factors in the process of dental morphologic diversification associated to regional and temporal ranges in this region of Argentina.
\end{abstract}

KEY WORDS: Bilateral asymmetry; Dental non-metric traits; Pre-conquest samples; Argentina.

\section{INTRODUCTION}

Dental morphology trait expressions have been used in anthropology and forensic sciences for determination of biological and geographical affiliations. Variations in morphology of crowns may be manifest in the primary and/ or permanent dentitions. Dental variation is heritable, is caused by multiple genes, and is little influenced by environmental factors (Rodríguez-Flórez et al., 2006). By mean of dental morphology analyses is possible an assessment to genetic population dynamics. Assuming the use of additive hereditary traits, the phenotypic differences among distinct groups or samples can be interpreted as differences in genotypic composition (Varela \& Cocilovo, 2000). Nonmetric dental traits are highly controlled by genetics and are relatively free of sex- and age-bias (Scott \& Turner, 1997). Therefore, phenetic (phenotypic) similarity can be said to approximate genetic similarity. The analysis of biological relatedness using dental nonmetric traits has proven reliable even in commingled samples when standardized procedures are followed (Ullinger et al., 2005). For these reasons, reconstruction of biological relationships between ancient human groups using teeth is an important research problem for South American bioarcheologist. The present study was carried out with a Calchaquí human PreConquest sample from Northwest of Argentina, with the aim of exploring the dental morphology patterns in this population (Bollini, 2004).

\section{MATERIAL AND METHOD}

Pre-Conquest human dental remains with reasonably reliable stratigraphic contexts are relatively rare from Northwest of Argentina (Salta, Catamarca, and Tucuman Provincies). Marcellino \& Colantonio (2000) suggest a Late Period between 0 and 1500 A.D for this sample. This study was carried out by means of a macroscopic analysis in permanent dentitions of 7 skulls (Fig. 1): 604-643-644-687602-601-471 (Museum Catalogue References). 40 dental non-mtetric traits were recorded. The ASU Dental

\footnotetext{
* Cátedra de Antropología Biológica II, Facultad de Ciencias Naturales, Universidad Nacional de La Plata - Argentina.

** Grupo de Investigaciones en Biología Humana GIBH, Departamento de Antropología y Sociología, Universidad de Caldas - Colombia.

*** Cátedra de Antropología Biológica y Cultural, Facultad de Ciencias Exactas, Físicas y Naturales, Universidad Nacional de Córdoba - Argentina. Consejo Nacional de Investigaciones Científicas y Técnicas (CONICET).
} 
Anthropology System was used to register the expression grade of all dental traits (Turner et al., 1991). The sample belong to División de Antropología del Museo de Ciencias Naturales (La Plata, Argentina). Binary record system was employed, grouping all grade expressions into both "presence" (1) and "absence" (0) categories.

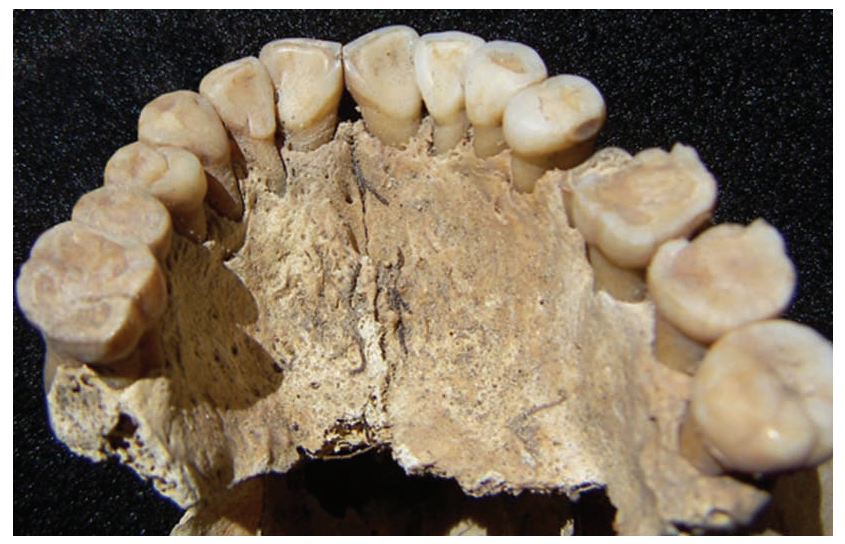

Fig. 1. Upper arcade of Calchaquí skull 643.

\section{RESULTS}

Frequencies of trait presence are in Table I. Percentages $>70 \%$ was found in 4 traits: shovel shape (UI1, UI2), and tuberculum dentale (UI2, UC). Values between 0.1 and $70 \%$ was found in 23: shovel shape (UC, LI1, LI2, LC), double shovel (UI1, UI2, UC, LI1, LI2, LC), interruption groove (UI1, UI2, LI1, LI2), tuberculum dentale (UI1, LI1, LI2), lingual cusp number (UP1, UP2, LP1, LP2), and hipocone (UM1, UM2). 13 traits was no found in this sample: tuberculum dentale (LC), Carabelli (UM1, UM2), paraconule (UM1, UM2), metaconule (UM1, UM2), entoconulid (LM1, LM2), metaconulid (LM1, LM2), and protostilyd (LM1, LM2).

\section{DISCUSSION}

Hanihara (1968) distinguished a characteristic dental pattern in East Asia peoples: high frequencies of shovel shape (UI1), entoconulid, deflecting wrinkle, and protostilyd (LM), all of which composing the "Mongoloid Dental Complex". Some years later, Turner (1976) describe two types of Mongoloid Dental Pattern namely Sundadont (Southeast Asian populations), and Sinodont (Northeast Asian populations). The Sinodont pattern evolved among populations from Asia and Americas about 20.000 to 11.000 years ago (Aung et al., 2005).
Devoto et al. describes high frequencies of shovel shape in UI1 and UI2 in early Atacama Indians (1967), Precolumbian Tastilian Indians (1971), and a Northwestern Argentinean population from Salta Province (1968). All his studies describe $100 \%$ of shovel shape presence in UI1 and near values for UI2 (between $70 \%$ and 99\%). In other samples analyzed previously of Araucanos (Bollini et al., 2006) and Chubut Region (Bollini et al., 2008b) from Patagonia, and Tastil Region (Bollini et al., 2008a), shovel shape presence in UI1 and UI2 is near values to the sample describe here.

Dahlberg (1947) describes high frequencies (100\%) of shovel shape in several American aborigines, such Pima Indians and Pueblo Indians. They show the same percentage observed in this paper. Nelson (1938) observed in Pecos Pueblos a high frecuency too for this trait (97.80\%.); Goldstein (1948) described $100 \%$ of shovel shape for Texas Indians and Sioux. The same percentage showed Pewenches Indians from Chile (Rothhammer et al., 1968).

Campusano et al. (1972) show a similar study on the same ethnic group (Diaguitas) with samples keep from $\mathrm{Mu}$ seo de Arqueología, La Serena in Chile. In this study, a Mongoloid and Sinodont categories is assumes by authors and a high frequency of shovel shape is describes (80\%) and absence of Carabelli's complex.

Calchaquí sample studied here is near to these values in shovel shape expression and Carabelli's complex, but the results of this study suggest that a Sinodont pattern is no clear for this sample. This consideration can be interpreted as a reflection of possible external factors in composition of total sample size. The use of morphological traits from the human dentition can create some problems of a methodological nature when studying archeological samples minor to 15 individuals. One issue is the assumption of dental trait expression as individually immutable, in the sense of being morphologically symmetrical between homologous teeth. In bioarcheology, estimating the frequency of a dental trait is influenced by the availability of samples and limited crown wear and the absence of caries (RodríguezFlórez \& Colantonio, 2007). Some authors recommend scoring the higher grade of expression for each dental trait (Turner \& Scott, 1977) or counting both the left and right sides for each individual (Haeussler et al., 1988). Frequencies finding in Calchaquí sample can be influences by a low sample size. To conclude, the present investigation provides additional, insightful elements for a biological description that can help us to identify more easily the possible biological factors in the process of dental morphologic diversification associated to regional and temporal ranges in this region of Argentina. 
BOLLiNi G. A.; RODRÍGUEZ-FLóREZ, C. D. \& COLANTONIO, S. E. Dental non-metric traits in a Pre-Conquest sample "Calchaquî" from Argentina, South America. Int. J. Morphol., 27(4):1063-1067, 2009.

Table I. Dental non-metric frequencies in the sample.

\begin{tabular}{|c|c|c|c|c|c|c|}
\hline \multicolumn{7}{|c|}{ UPPER PERMANENT DENTITION } \\
\hline Tooth type & Trait & Dichotomy & Presence & Absence & $\mathrm{k}$ & $\%$ \\
\hline \multirow[t]{4}{*}{ UI1 } & Shovel shape & $0-3$ & $1-3$ & 0 & 5 & 0,71 \\
\hline & Double shovel & $0-4$ & $1-4$ & 0 & 1 & 0,14 \\
\hline & Tuberculum dentale & $0-3$ & $1-3$ & 0 & 2 & 0,28 \\
\hline & Interruption groove & $0-1$ & 1 & 0 & 1 & 0,14 \\
\hline \multirow[t]{4}{*}{ UI2 } & Shovel shape & $0-3$ & $1-3$ & 0 & 5 & 0,71 \\
\hline & Double shovel & $0-4$ & $1-4$ & 0 & 3 & 0,42 \\
\hline & Tuberculum dentale & $0-3$ & $1-3$ & 0 & 5 & 0,71 \\
\hline & Interruption groove & $0-1$ & 1 & 0 & 3 & 0,42 \\
\hline \multirow[t]{3}{*}{$\mathrm{UC}$} & Shovel shape & $0-3$ & $1-3$ & 0 & 4 & 0,57 \\
\hline & Double shovel & $0-4$ & $1-4$ & 0 & 4 & 0,57 \\
\hline & Tuberculum dentale & $0-3$ & $1-3$ & 0 & 6 & 0,85 \\
\hline UP1 & Lingual cusp number & $1-3$ & $2-3$ & 1 & 3 & 0,42 \\
\hline UP2 & Lingual cusp number & $1-3$ & $2-3$ & 1 & 3 & 0,42 \\
\hline \multirow[t]{4}{*}{ UM1 } & Hypocone & $0-3$ & $1-3$ & 0 & 1 & 0,14 \\
\hline & Carabelli & $0-4$ & $1-4$ & 0 & 0 & 0,00 \\
\hline & Paraconule & $0-1$ & 1 & 0 & 0 & 0,00 \\
\hline & Metaconule & $0-1$ & 1 & 0 & 0 & 0,00 \\
\hline \multirow[t]{4}{*}{ UM2 } & Hypocone & $0-3$ & $1-3$ & 0 & 1 & 0,14 \\
\hline & Carabelli & $0-4$ & $1-4$ & 0 & 0 & 0,00 \\
\hline & Paraconule & $0-1$ & 1 & 0 & 0 & 0,00 \\
\hline & Metaconule & $0-1$ & 1 & 0 & 0 & 0,00 \\
\hline \multicolumn{7}{|c|}{ LOWER PERMANENT DENTITION } \\
\hline \multirow[t]{4}{*}{ LI1 } & Shovel shape & $0-3$ & $1-3$ & 0 & 1 & 0,14 \\
\hline & Double shovel & $0-4$ & $1-4$ & 0 & 1 & 0,14 \\
\hline & Tuberculum dentale & $0-3$ & $1-3$ & 0 & 1 & 0,14 \\
\hline & Interruption groove & $0-1$ & 1 & 0 & 1 & 0,14 \\
\hline \multirow[t]{4}{*}{ LI2 } & Shovel shape & $0-3$ & $1-3$ & 0 & 1 & 0,14 \\
\hline & Double shovel & $0-4$ & $1-4$ & 0 & 1 & 0,14 \\
\hline & Tuberculum dentale & $0-3$ & $1-3$ & 0 & 1 & 0,14 \\
\hline & Interruption groove & $0-1$ & 1 & 0 & 1 & 0,14 \\
\hline \multirow[t]{3}{*}{ LC } & Shovel shape & $0-3$ & $1-3$ & 0 & 2 & 0,28 \\
\hline & Double shovel & $0-4$ & $1-4$ & 0 & 2 & 0,28 \\
\hline & Tuberculum dentale & $0-3$ & $1-3$ & 0 & 0 & 0,00 \\
\hline LP1 & Lingual cusp number & $0-3$ & $1-3$ & 0 & 2 & 0,28 \\
\hline LP2 & Lingual cusp number & $0-3$ & $1-3$ & 0 & 2 & 0,28 \\
\hline \multirow[t]{3}{*}{ LM1 } & Entoconulid & $0-1$ & 1 & 0 & 0 & 0,00 \\
\hline & Metaconulid & $0-1$ & 1 & 0 & 0 & 0,00 \\
\hline & Protostilyd & $0-1$ & 1 & 0 & 0 & 0,00 \\
\hline \multirow[t]{3}{*}{ LM2 } & Entoconulid & $0-1$ & 1 & 0 & 0 & 0,00 \\
\hline & Metaconulid & $0-1$ & 1 & 0 & 0 & 0,00 \\
\hline & Protostilyd & $0-1$ & 1 & 0 & 0 & 0,00 \\
\hline
\end{tabular}


AKNOWLEDMENTS. We wish acknowledge to Cecilia Ferreira by helping in record and laboratory assistance.
This article is in memory of Dr. Jorge Eduardo Bollini (R.I.P.).

BOLLINI G. A.; RODRÍGUEZ-FLÓREZ, C. D. \& COLANTONIO, S. E. Rasgos dentales no-métricos en una serie Pre-Conquista "Calchaquí" de Argentina, América del Sur. Int. J. Morphol., 27(4):1063-1067, 2009.

RESUMEN: Estudiamos una muestra Pre-Conquista de Calchaquíes del Noroeste de Argentina, con el objetivo de explorar patrones de morfología dental presentes en esta población. Se realizó un análisis macroscópico en dentición permanente de 7 cráneos. 40 rasgos no-dentales fueron registrados utilizando el ASU Dental Antropology System. Porcentajes mayores al 70\% fueron encontrados solamente en 4 rasgos. La muestra estudiada está cerca de valores en la expresión de la forma de pala, pero los resultados de este estudio sugieren que un patrón Sinodonte no es claro para esta muestra. Para concluir, la presente investigación brinda adicionalmente, profundos elementos para una descripción de los factores biológicos en el proceso de diversificación morfológica dental asociada a los rangos regionales y temporales en esta región de Argentina.

PALABRAS CLAVE: Asimetría bilateral; Rasgos dentales no-métricos; Muestra Pre-Conquista; Argentina.

\section{REFERENCES}

Aung, N. N.; Saruwatari, L.; Bo, B.; Sakai, E.; Manabe, Y. \& Ohno, N. Dental traits among five tribes in Myanmar (Burma). J. Oral Biosci., 47(3):272-9, 2005.

Bollini, G. A. Análisis de las distancias biológicas según la dentición en poblaciones aborígenes argentinas. Tesis Doctoral. Universidad Nacional de La Plata, Argentina, 2004.

Bollini, G. A.; Rodríguez-Flórez, C. D. \& Colantonio, S. E. Dental non-metric traits in a pre-conquest sample from Tastil region in Argentina, South America. Bull. Int. Assoc. Paleodont., 2(1):19-25, 2008a.

Bollini, G. A.; Rodríguez-Flórez, C. D. \& Colantonio, S. E. Dental non metric traits in a pre-conquest sample from Chubut region in Patagonia (Argentina), South America. Dental Anthropology, 21(2):50-3, 2008b.

Bollini, G. A.; Rodríguez-Flórez, C. D.; Colantonio, S. E. \& Méndez, M. G. Morfología dental de una serie prehistórica de araucanos provenientes de la Patagonia argentina y su relación biológica con otras poblaciones prehistóricas argentinas y del mundo. Int. J. Morphol., 24(4):705-12, 2006.

Campusano, C., Figueroa, H., Lazo B., Pinto-Cisternas J. \& Salinas, C. Some dental traits of Diaguita indian skulls. Am. J. Phys. Anthropol., 36:139-42, 1972.

Dahlberg, A. A. The dentitions of american Indians. Papers on the Physical Anthropology of the American Indians.
Fourth Viking Fund Summer Seminar. New York, The Viking Fund, Inc., 1947. pp.138-76.

Devoto, F. C. H. Shovel-shaped incisors in Pre-columbian Tastilian indians. J. Dent. Res., 50(1):168, 1971.

Devoto, F. C. H.; Arias, N. H.; Ringuelet, S. \& Palma, N. H. Shovel-shaped incisors in a Northwertern Argentine population. J. Dent. Res., 47(5):820-3, 1968.

Haeussler, A. M.; Turner, C. G. $2^{\text {nd }}$. \& Irish, J. D. Concordance of American and Soviet methods in dental anthropology. Am. J. Phys. Anthropol., 75:218, 1988.

Hanihara, K. Mongoloid dental complex in the permanent dentition. Proceedings of the VIII ${ }^{\text {th }}$ International Symposium of Anthropological and Ethnological Sciences. Tokyo and Kyoto, Science Council of Japan, 1968. pp. 298-300.

Marcellino, A. J. \& Colantonio, S. E. Los cráneos aborígenes más antiguos de la Argentina: Un ensayo clasificatorio. En: Caro Dobón, L.; Rodríguez Otero, H. \& Sánchez Compadre, E. (edit) Tendencias actuales de investigación en la Antropología Física española. León, España, Editorial Universidad de León, 2000. pp. 20518.

Nelson, C. T. The teeth of the Indians Pecos Pueblo. Am. J. Phys. Anthropol., 23:261-93, 1938.

Rodríguez-Flórez, C. D. \& Colantonio, S. E. Bilateral 
BOLLINI G. A.; RODRÍGUEZ-FLÓREZ, C. D. \& COLANTONIO, S. E. Dental non-metric traits in a Pre-Conquest sample "Calchaquî" from Argentina, South America. Int. J. Morphol., 27(4):1063-1067, 2009.

asymmetry of upper permanent dentition in six archaeological pre-conquest samples from Colombia, South America. Dental Anthropology, 20:14-8, 2007.

Rodríguez-Flórez, C. D.; Fonseca, G. M. \& Villalba, M. T. Brief communication: Occurrence of an eighth cusp on primary second mandibular molars of a contemporary Argentinean child. Dental Anthropology 19(3):73-5, 2006.

Rothhammer, F.; Lasserre, R.; Blanco, R.; Covarrubias, E. \& Dixon, M. Microevolution in human Chilean populations. IV. Shovel shape, mesial-palatal version and other dental traits in Pewenche Indians. Z. Morphol. Anthropol., 60:162-9, 1968.

Scott, R. G. \& Turner, C. G. $2^{\text {nd }}$. The anthropology of modern human teeth: Dental morphology and its variation in recent human populations. Cambridge, Cambridge University Press, 1997.

Tuner, C. G. $2^{\text {nd }}$. Dental evidence on the origins of the Ainu and Japanese. Science, 193:911-3, 1976.

Turner, C. G. $2^{\text {nd }}$; Nichol, C. R. \& Scott, G. R. Scoring procedures for key morphological traits of the permanent dentition: The Arizona State University Dental Anthropology System. In: Advances in Dental Anthropology, Kelley M. A. \& Larsen C. S. (eds.), New York, Wiley-Liss Inc., 1991. pp.13-31.

Turner, C. G. $2^{\text {nd }} \&$ Scott, G. R. The dentition of Easter Islanders. In: Dahlberg, A. A. \& Graber, T. M. (editors). Orofacial growth and development. The Hague, Mouton. 1977. pp. 229-49.

Ullinger, J. M.; Sheridan, S. G.; Hawkey, D. E.; Turner, C. G, \& Cooley, R. Bioarchaeological analysis of cultural transition in the Southern levant using dental nonmetric traits. Am. J. Phys. Anthropol., 128:466-76, 2005.

Varela, H. H. \& Cocilovo, J. A. Structure of the prehistoric population of San Pedro de Atacama. Curr. Anthropol., 41(1):125-31, 2000.
Correspondence to:

Carlos David Rodríguez-Flórez,

Grupo de Investigaciones en Biología Humana GIBH

Departamento de Antropología y Sociología

Universidad de Caldas

COLOMBIA

E-mail: bioarqueologia@ucaldas.edu.co

Received: 25-02-2009

Accepted: 08-09-2009 
